\title{
Pre-S2 and HBV associated hepatocellular carcinoma
}

\author{
Ying Zheng, Yan-Yan Qian, Hong Fan
}

The Key Laboratory of Developmental Genes and Human Diseases, Department of Medical Genetics and Developmental Biology, Medical School, Southeast University, Nanjing 210009, China.

Correspondence to: Prof. Hong Fan, The Key Laboratory of Developmental Genes and Human Diseases, Department of Medical Genetics and Developmental Biology, Medical School, Southeast University, Dingjiaqiao \#87, Nanjing 210009, China.

E-mail: fanh@seu.edu.cn

How to cite this article: Zheng Y, Qian YY, Fan H. Pre-S2 and HBV associated hepatocellular carcinoma. Hepatoma Res 2018;4:17. http://dx.doi.org/10.20517/2394-5079.2018.08

Received: 24 Feb 2018 First Decision: 28 Mar 2018 Revised: 14 May 2018 Accepted: 14 May 2018 Published: 31 May 2018

Science Editor: Guang-Wen Cao Copy Editor: Guang-Zhe Zhu Production Editor: Cai-Hong Wang

\begin{abstract}
Hepatitis B virus (HBV) infection is a primary cause of hepatocellular carcinoma (HCC). Under selection pressures of host immunity and/or immunoprophylaxis and antiviral therapies, HBV evolves by accumulating mutations in its genome. Several studies highlighted the considerable importance of HBV surface (HBs) protein mutants (pre-S/S variants) in tumorigenesis. Among those mutants, pre-S2 mutants have been recognized as "precursor lesions of HCC" and as risk factors for post-operative recurrence of HCC. Pre-S2 mutants play important roles in tumor progression and induce various mechanisms of tumorigenesis. These roles include that the cytoplasmic orientation of the pre-S2 domain is essential for the transcriptional activator C-terminally truncated middle surface protein (MHBst) which participates in the development of hepatocellular carcinoma. Pre-S2 mutants may also play important roles in HBV tumorigenesis by inducing both endoplasmic reticulum stress-dependent and endoplasmic reticulum (ER) stress-independent pathways. Because HCC has poor prognosis and its incidence is increasing, methods for the prevention and treatment of HCC should be comprehensive. Emerging treatments based on ER stress may provide a new strategy.
\end{abstract}

Keywords: Pre-S2, hepatocellular carcinoma, hepatitis B virus, endoplasmic reticulum stress

\section{INTRODUCTION}

More than 240 million individuals worldwide are infected with chronic hepatitis B virus (HBV) $)^{[1]}$. Chronic HBV infection progresses to cirrhosis in up to $40 \%$ of untreated patients, and there is an associated risk of decompensated cirrhosis and hepatocellular carcinoma ${ }^{[2-6]}$. Several hypotheses have been proposed to

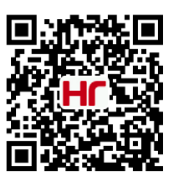


explain the mechanisms of HBV related to tumorigenesis, including inflammation, liver regeneration associated with cytotoxic immune injuries and transcriptional activators of mutant HBV gene products ${ }^{[7-10]}$. The HBV genome consists of a circular, partly double-stranded DNA with four overlapping open reading frames: (1) the pre-S/S open reading frame (ORF) encodes three viral surface proteins [including hepatitis B surface antigen (HBsAg)/HBV surface (HBs)], (2) the pre-C/C ORF encodes the hepatitis B e antigen ( $\mathrm{HBeAg}$ ) and the hepatitis B core antigen ( $\mathrm{HBcAg})$, (3) the P ORF encodes the terminal protein (TP) and the viral polymerase that possess DNA polymerase and reverse transcriptase and $\mathrm{RNaseH}$ activities, and (4) the $\mathrm{X}$ gene encoding for a transcriptional transactivator, hepatitis $\mathrm{B}$ virus $\mathrm{X}$ protein $(\mathrm{HBx})$, which is essential for virus replication ${ }^{[11,12]}$.

Among the four functional proteins encoded by HBV (X, surface, core, and polymerase), HBx and HBs (mutant) proteins are designated "viral oncoproteins"[13]. The pre-S/S mutants of HBV are considered "precursor lesions" of hepatocellular carcinoma (HCC) ${ }^{[14]}$ and as risk factors for the post-operative recurrence of $\mathrm{HCC}^{[15,16]}$. Various pre-S/S mutants contribute to HCC tumorigenesis via various mechanisms, including transactivation of transcription factors, the endoplasmic reticulum (ER) stress-dependent pathway, the ER stress-independent pathway, and others. Among these mutants, pre-S2 mutants showed significant correlations with HCC and have been widely considered novel biomarkers of HBV-associated HCC ${ }^{[13,17]}$. The malignant transformation potential of pre-S2 mutation has been confirmed in an immortalized human hepatocyte line $\mathrm{HH} 411^{[18]}$. In transgenic mice, pre-S2 mutants induced dysplasia of hepatocytes and development of $\mathrm{HCC}^{[19]}$, suggesting that pre-S2 plays a key role in HCC tumor progression.

In this mini-review, we discussed the relationship between pre-S2 mutations and HCC, as well as the underlying molecular mechanisms and treatments based on HBV tumorigenesis induced by pre-S2.

\section{STRUCTURE AND ROLE OF PRE-S IN HBV}

$\mathrm{HBV}$ is a small, enveloped 3.2-kb DNA virus with four open reading frames. The HBV envelope is composed of three forms of HBsAg, including the large (encoded by the pre-S1/S2/S gene), middle (pre-S2/S gene) and small ( $\mathrm{S}$ gene) envelope proteins ${ }^{[20,21]}$. In addition, truncated and mutated pre-S2/S [the large HBV surface protein (LHBs) and truncated middle surface protein (MHBs)] or HBx proteins are produced by integrated viral sequences ${ }^{[22-24]}$. The pre-S region has been reported to mediate hepatocyte attachment of the virus, containing $\mathrm{B}$ cell and $\mathrm{T}$ cell epitopes ${ }^{[25,26]}$, a binding site for neutralizing anti-pre-S2 antibody ${ }^{[27,28]}$, and an S promoter for controlling the production of middle and small HBs proteins. Under endogenous (host immunity) and/or exogenous (immunoprophylaxis and antiviral therapies) selection pressures, HBV evolves by accumulating mutations in its genome, resulting in HBV variants with altered epitopes providing higher pathogenicity ${ }^{[29-31]}$. In this context, a growing number of studies were performed to evaluate various HBV genotypes; these pointed out the considerable importance of $\mathrm{HBV}$ envelope protein mutants (preS/S variants) ${ }^{[32,33]}$. Naturally occurring pre-S mutations are frequently detected in serum obtained from patients with chronic HBV infection ${ }^{[34]}$. Furthermore, pre-S mutations were more common in chronic HBV infection and were related to disease progression and HCC. Currently, the most frequently reported variations are the pre-S deletion mutation and the pre-S2 start codon mutation ${ }^{[19,31,35-37]}$. In particular, the pre-S2 mutation often coincides with changes in human immune cell epitopes ${ }^{[38]}$ and is more significantly correlated with HCC than pre-S1 mutation ${ }^{[39]}$.

\section{THE ASSOCIATION BETWEEN PRE-S MUTATIONS AND HCC}

The notion of pre-S/S mutations as causes of HBV immune escape was supported by the identification of individuals who developed HBV infection in spite of having vaccine-induced circulating anti-HBs antibodies $^{[31,32,40]}$. Apart from the ability to avoid neutralization by vaccine-induced anti-HBs, these pre-S/S mutations may also have accounted for cases of occult HBV infection ${ }^{[3,41]}$. Furthermore, pre-S/S mutations 
have been found in association with various forms of acute and chronic liver disease, including fulminant hepatitis (FH), fibrosing cholestatic hepatitis $(\mathrm{FCH})$ and cirrhosis ${ }^{[2-44]}$. Both pre-S1 and pre-S2 mutants led to defective secretion of mutant large surface antigens which then accumulated in ER, leading to ground glass hepatocytes (GGH) formation in chronic HBV infection ${ }^{[45,46]}$. Under electron microscopy, GGHs were characterized by an abundance of ER, and overloaded ER made the cytoplasm of GGH become "foggy" or "glassy". GGH was recognized as a risk factor for HCC, in particular, type II GGHs that harbor pre-S2 mutations accumulated on the ER of hepatocytes were considered biomarkers of HCC and were helpful in predicting recurrence and survival in HBV-infected HCC patients ${ }^{[47]}$. Previous studies reported several tumorigenic mutants, including $\mathrm{SL} 95^{*}, \mathrm{sW} 182^{*}$, and $\mathrm{sL} 216^{*}$, that did not promote ER stress but rather activated cell proliferation and transformational abilities; the sW182* mutant was demonstrated to have potent tumorigenic activity ${ }^{[48]}$; MHBst167 mutants have been shown to interact with proteins associated with tumor progression/progression in vitro ${ }^{[49]}$. A recent study reported that a pre-S2 start codon mutation of HBV subgenotype B3 affected nuclear factor $\kappa \mathrm{B}(\mathrm{NF}-\kappa \mathrm{B})$ expression and activation in Huh7 cell lines ${ }^{[50]}$.

The frequency of pre-S mutations increased successively in the various stages of chronic hepatitis B (CHB) infection. A meta-analysis showed that the frequency of pre-S mutants was approximately $10 \%, 20 \%, 35 \%$, and 50\% in asymptomatic HBsAg carriers, CHB patients, patients with liver cirrhosis and HCC patients, respectively ${ }^{[39]}$. The prevalence of pre-S mutants varied among countries with endemic HBV genotypes with a higher prevalence of genotypes $\mathrm{B}$ and $\mathrm{C}^{[51]}$. Pre-S deletion mutants detected in serum were also reported to increase the risk of post-operative recurrence of $\mathrm{HCC}^{[15]}$. To efficiently detect pre-S deletion mutants in serum, Su et al. ${ }^{[7]}$ successfully developed an oligonucleotide pre-S gene chip to detect pre-S deletion mutations in sera as a predictive hallmark of HCC. Combined detection of pre-S mutations and other markers of HBV replication such as HBeAg and viral loads may offer a reliable method for predicting HCC risks in chronic HBV carriers. Among those mutants, the pre-S2 mutation in particular was found to be significantly associated with the risk of HCC development ${ }^{[2,31,52-55]}$. Pre-S2 deletion mutations in sera can be detected in nearly half of children with $\mathrm{HCC}^{[56]}$, and in tissue samples, pre-S2 deletion mutations can be detected in about $80 \%$ of pediatric $\mathrm{HCC}^{[57]}$.

\section{VARIOUS MECHANISMS OF PRE-S2 CONTRIBUTING TO HCC Pre-S2 transcriptional activator proteins}

During the infectious process, HBV DNA integrates into hepatocellular chromosomes and encodes two transcriptional activators: the HBV X protein and the family of the pre-S2 activator proteins of $\mathrm{HBV}$, including the LHBs and C-terminally $\mathrm{MHBst}^{[23]}$. The pre-S/S genomic region, when deleted in the C-terminus portion (including the viral transmembrane hydrophobic region III of the $\mathrm{S}$ domain) produces C-terminally truncated middle surface protein ${ }^{[31]}$. HBs transactivators (LHBs and MHBst) function based by cytoplasmic orientation of the pre-S2 domain ${ }^{[58]}$. Unlike full-length MHBs, truncated MHBst is retained in the endoplasmic reticulum and is not secreted. Therefore, the pre-S2 region of MHBst can interact with the cytoplasmic protein in the cytoplasmic region, resulting in transcriptional activation ${ }^{[9,60]}$.

The discovery of transactivating functions exerted by LHBs and MHBst supports the notion that transactivation of cellular gene expression could be relevant to hepatocarcinogenesis. Pre-S2 activators LHBs and MHBst exerted tumor promoter-like functions by activating c-Raf-1/Erk2 signaling in transgenic mice, leading to enhanced proliferative activity of hepatocytes ${ }^{[58]}$, Liang et al ${ }^{[6]]}$ found that overexpressing MHBst in hepatoma cells enhanced TNF-related apoptosis-inducing ligand (TRAI)-induced apoptosis. In addition, a study showed that pre-S2, functioning as a transcriptional activator, promoted the development of hepatocellular carcinoma by activating oncogenes, including c-myc, human telomerase reverse transcriptase (hTERT) and forkhead box $\mathrm{P} 3(\mathrm{Foxp} 3)^{[18,22,23,62]}$. Another recent study provided evidence that HBV protein pre-S2 was responsible for reactivation of two oncogenes, alpha-fetoprotein (AFP) and glypican 3 (GPC3), in $\mathrm{HCC}^{[63]}$. Other studies reported that pre-S2 increased protein levels of transcriptional co-activators with 
PDZ-binding motifs (TAZ), thereby playing oncogenic roles in HCC cells by repressing miRNA-338-3p expression, implicating hepatocarcinogenesis ${ }^{[4-66]}$.

\section{Pre-S2 mutants}

Both pre-S1 and pre-S2 mutants led to defective secretion of mutant large surface antigens that then accumulated in the ER, leading to GGH formation in chronic HBV infections. As mentioned above, type II GGHs that harbored pre-S2 mutations accumulating on the ER of hepatocytes were considered biomarkers of $\mathrm{HCC}^{[47]}$. HBV proteins utilize the ER protein folding machinery and cellular secretory pathway ${ }^{[67]}$. Therefore, the underlying mechanisms of pre-S mutations contributing to HCC may be involved in ER stress $^{[7]}$. ER stress, also called the UPR in mammalian cells, is a cellular defense mechanism that responds to unfolded viral proteins or perturbed ER functions ${ }^{[19]}$. Expression of viral gene products is detected by three UPR sensors, including two ER transmembrane kinases (IRE1 and PERK), and one ER transmembrane transcription factor (ATF-6). The three UPR sensors are associated with ER chaperone GRP78/BiP at rest, and are dissociated from GRP78 upon ER stress ${ }^{[68]}$. Induction of GRP78 prevented cells from apoptosis, and ER stress-regulated translation increased tolerance to extreme hypoxia and then promoted tumor growth $^{[69,70]}$. The activation of ER-stress downstream molecules such as ATF-6, GRP78 and XBP-1 is believed to be involved in hepatocarcinogenesis ${ }^{[71]}$.

Both types of pre-S mutants cause overproduction and accumulation of mutated envelope proteins in the ER, and the accumulation of mutant or unfolded proteins cause stress in the ER that is sensed by the glucose-regulated protein 78 (GRP78). Unfolded proteins sequester GRP78 and dissociate from three ER transmembrane transducers leading to their activation; this leads to significant ER stress that may lead to oxidative stress and DNA damage ${ }^{[72]}$, resulting in genomic instability ${ }^{[73]}$ and ultimately development of $\mathrm{HCC}^{[74,75]}$. A detailed study aimed at delineating the molecular mechanisms of pre-S mutant-induced genomic instability suggested that pre-S2 mutant large surface protein inhibited DNA double-strand break repair and led to genome instability in hepatocarcinogenesis; this represented a promising high-risk HCC biomarker in chronic HBV carriers ${ }^{[76]}$. The ER stress initiated by the pre-S mutants activated two pathways that protect hepatocytes from apoptosis, one involving nuclear factor (NF)- $\kappa B$ to upregulate cyclooxygenase-2 $(\mathrm{COX}-2)^{[45,7]]}$ and the other involving vascular endothelial growth factor to activate AKT/mammalian target of rapamycin (mTOR) signaling ${ }^{[7]}$. The mammalian target of mTOR is a highly conserved serine/ threonine kinase that controls cell growth and proliferation ${ }^{[78]}$. Pre-S2 mutations promoted tumorigenesis by sustaining high activation rates of aerobic glycolysis through the mTOR signal cascade ${ }^{[79]}$. In addition, the pre-S2 mutation LHBs induced an ER stress-independent c-Jun activation domain binding protein 1 (JAB1)/p27/retinoblastoma (Rb)/adenovirus E2 promoter binding factor/cyclin A signal to initiate cell cycle progression $^{[75]}$. These studies suggested that the combined effects of genomic instability and cell proliferation potentially resulted in carcinogenesis ${ }^{[7]}$.

\section{TREATMENT STRATEGIES BASED ON ER STRESS}

One of the strategies used to prevent HBV-associated liver diseases and HCC is vaccination ${ }^{[80]}$. The effectiveness in preventing blood-borne transmission from an infected mother to her newborn was about $90 \%{ }^{[81]}$, however therapeutic vaccines for the treatment of established HBV infection are not available ${ }^{[82,83]}$. Two antiviral therapies have been approved: pegylated alpha interferon and nucleoside/nucleotide analogues $(\mathrm{NA})^{[84]}$. NA therapy has antiviral effects that reduce HCC development and post-operative recurrence of HCC $^{[85]}$. NA treatment affects the reverse transcription of pregenomic RNA but does not affect cDNA and subgenomic RNA that have translational activity associated with HBsAg levels. Thus, current NA therapy can hardly clear $\mathrm{HBsAg}^{[13]}$. Subsequent studies also showed that pre-S2 mutations induced resistance to NAs and predicted HCC development ${ }^{[8]}$. Related studies showed that interferon treatment, more than NA treatment, inhibited HBsAg and pre-S mutant protein ${ }^{[53,87,88]}$. However, these antivirals therapy often failed to eradicate the virus completely, and their efficacy in preventing liver cirrhosis and HCC was limited ${ }^{[89,90]}$. 
Thus, it is necessary to clarify the details of the host-virus relationship during HBV infection to facilitate the development of efficient therapeutic strategies for HBV infection.

To prevent HCC, targeting HBV-induced ER stress may provide novel strategies in high-risk CHB. Antioxidants may be such ideal agents, because they reduce ER stress, thereby improving protein folding ${ }^{[91]}$. Natural products, including silymarin and resveratrol, have been used in HCC. The two drugs target ER stress-associated signal pathways ${ }^{[7]}$. The pre-S2 mutant initiated an mTOR-dependent glycolytic pathway to activate the solute carrier family 2 member 1 (SLC2A1), contributing to aberrant glucose uptake and lactate production in advanced stages of pre-S2 mutant transgenic tumorigenesis; the mTOR signaling cascade in pre-S2 mutant-mediated hepatocarcinogenesis was inhibited by the combined treatment of resveratrol and silymarin $^{[79]}$. However, these findings require further validation. Glycyrrhizin acid (GA) has also been reported to suppress ER stress in acute liver injury via several functions, including effective hepatoprotection and the reduction of elevated transaminases ${ }^{[92]}$. Long-term treatment with glycyrrhizin prevented HCC development in chronic hepatitis $\mathrm{C}$ infection ${ }^{[93]}$. Together, these strategies for prevention and treatment of HBV-related HCC should be further investigated.

\section{DECLARATIONS}

\section{Authors' contributions}

Drafted the manuscript: Zheng Y

Revised the manuscript: Qian YY

Revised and approved the final version: Fan $\mathrm{H}$

\section{Financial support and sponsorship}

This work was funded by the grants from National Natural Science Foundation of China (81672414, 81472548, and 81702906).

\section{Conflicts of interest}

There are no conflicts of interest.

\section{Patient consent}

Not applicable.

\section{Ethics approval}

Not applicable.

\section{Copyright}

(c) The Author(s) 2018.

\section{REFERENCES}

1. Schweitzer A, Horn J, Mikolajczyk RT, Krause G, Ott JJ. Estimations of worldwide prevalence of chronic hepatitis B virus infection: a systematic review of data published between 1965 and 2013. Lancet 2015;386:1546-55.

2. Sarin SK, Kumar M, Lau GK, Abbas Z, Chan HL, Chen CJ, Chen DS, Chen HL, Chen PJ, Chien RN, Dokmeci AK, Gane E, Hou JL, Jafri W, Jia J, Kim JH, Lai CL, Lee HC, Lim SG, Liu CJ, Locarnini S, Al Mahtab M, Mohamed R, Omata M, Park J, Piratvisuth T, Sharma BC, Sollano J, Wang FS, Wei L, Yuen MF, Zheng SS, Kao JH. Asian-Pacific clinical practice guidelines on the management of hepatitis B: a 2015 update. Hepatol Int 2016;10:1-98.

3. Tang LSY, Covert E, Wilson E, Kottilil S. Chronic hepatitis B infection: a review. JAMA 2018;319:1802-13.

4. Fattovich G. Natural history and prognosis of hepatitis B. Semin Liver Dis 2003;23:47-58.

5. Poh Z, Goh BB, Chang PE, Tan CK. Rates of cirrhosis and hepatocellular carcinoma in chronic hepatitis B and the role of surveillance: a 10-year follow-up of 673 patients. Eur J Gastroenterol Hepatol 2015;27:638-43.

6. Yang JD, Kim WR, Coelho R, Mettler TA, Benson JT, Sanderson SO, Therneau TM, Kim B, Roberts LR. Cirrhosis is present in most 
patients with hepatitis B and hepatocellular carcinoma. Clin Gastroenterol Hepatol 2011;9:64-70.

7. Su LJ, Wang LH, Hsieh WC, Wu HC, Teng CF, Tsai HW, Huang W. The emerging role of hepatitis B virus pre-S2 deletion mutant proteins in HBV tumorigenesis. J Biomed Sci 2014;21:98.

8. Su LJ, Hsieh WC, Tsai HW, Wu HC. Chemoprevention and novel therapy for hepatocellular carcinoma associated with chronic hepatitis B virus infection. Hepatobiliary Surg Nutr 2013;2:37-9.

9. Sitia G, Aiolfi R, Di Lucia P, Mainetti M, Fiocchi A, Mingozzi F, Esposito A, Ruggeri ZM, Chisari FV, Iannacone M. Guidotti LG. Antiplatelet therapy prevents hepatocellular carcinoma and improves survival in a mouse model of chronic hepatitis B. Proc Natl Acad Sci U S A 2012;109:E2165-72.

10. Liaw YF, Chu CM. Hepatitis B virus infection. Lancet 2009;373:582-92.

11. Liu S, Koh SS, Lee CG. Hepatitis B virus X protein and hepatocarcinogenesis. Int J Mol Sci 2016;17:179.

12. Neuveut C, Wei Y, Buendia MA. Mechanisms of HBV-related hepatocarcinogenesis. J Hepatol 2010;52:594-604.

13. Li YW, Yang FC, Lu HQ, Zhang JS. Hepatocellular carcinoma and hepatitis B surface protein. World J Gastroenterol 2016;22:1943-52.

14. Su LJ, Wang HC, Wu HC, Huang WY. Ground glass hepatocytes contain pre-S mutants and represent preneoplastic lesions in chronic hepatitis B virus infection. J Gastroenterol Hepatol 2008;23:1169-74.

15. Su CW, Chiou YW, Tsai YH, Teng RD, Chau GY, Lei HJ, Hung HH, Huo TI, Wu JC. The influence of hepatitis B viral load and pre-S deletion mutations on post-operative recurrence of hepatocellular carcinoma and the tertiary preventive effects by anti-viral therapy. PLoS One 2013;8:e66457.

16. Yen CJ, Ai YL, Tsai HW, Chan SH, Yen CS, Cheng KH, Lee YP, Kao CW, Wang YC, Chen YL, Lin CH, Liu T, Tsai HP, Wang JR, Su LJ, Huang W. Hepatitis B virus surface gene pre-S2 mutant as a high-risk serum marker for hepatoma recurrence after curative hepatic resection. Hepatology 2018; doi: 10.1002/hep.29790.

17. Qu LS, Chen YY, Zhang HF, Liu JX, Lu CH. Pre-S deletions of hepatitis B virus predict recurrence of hepatocellular carcinoma after curative resection. Medicine 2017;96:e8311.

18. Wang HC, Chang WT, Chang WW, Wu HC, Huang W, Lei HY, Lai MD, Fausto N, Su LJ. Hepatitis B virus pre-S2 mutant upregulates cyclin A expression and induces nodular proliferation of hepatocytes. Hepatology 2005;41:761-70.

19. Wang HC, Huang W, Lai MD, Su LJ. Hepatitis B virus pre-S mutants, endoplasmic reticulum stress and hepatocarcinogenesis. Cancer Sci 2006;97:683-8.

20. Sinn DH, Choi MS, Gwak GY, Paik YH, Lee JH, Koh KC, Paik SW, Yoo BC. Pre-s mutation is a significant risk factor for hepatocellular carcinoma development: a long-term retrospective cohort study. Dig Dis Sci 2013;58:751-8.

21. Tiollais P, Pourcel C, Dejean A. The hepatitis B virus. Nature 1985;317:489-95.

22. Luan F, Liu H, Gao L, Liu J, Sun Z, Ju Y, Hou N, Guo C, Liang X, Zhang L, Sun W, Ma C. Hepatitis B virus protein preS2 potentially promotes HCC development via its transcriptional activation of hTERT. Gut 2009;58:1528-37.

23. Hildt E, Hofschneider PH. The PreS2 activators of the hepatitis B virus: activators of tumour promoter pathways. Recent Results Cancer Res 1998;154:315-29.

24. Schluter V, Meyer M, Hofschneider PH, Koshy R, Caselmann WH. Integrated hepatitis B virus X and 3' truncated preS/S sequences derived from human hepatomas encode functionally active transactivators. Oncogene 1994;9:3335-44.

25. Milich DR, McNamara MK, McLachlan A, Thornton GB, Chisari FV. Distinct H-2-linked regulation of T-cell responses to the pre-S and $\mathrm{S}$ regions of the same hepatitis B surface antigen polypeptide allows circumvention of nonresponsiveness to the $\mathrm{S}$ region. Proc Natl Acad Sci U S A 1985;82:8168-72.

26. Milich DR, Thornton GB, Neurath AR, Kent SB, Michel ML, Tiollais P, Chisari FV. Enhanced immunogenicity of the pre-S region of hepatitis B surface antigen. Science 1985;228:1195-9.

27. Berthelot P, Neurath R, Courouce AM, Brechot C, Degos F, Tron F, Girard M. Hepatitis B vaccines with pre-S gene product. Lancet 1986;1:1150.

28. Neurath AR, Adamowicz P, Kent SB, Riottot MM, Strick N, Parker K, Offensperger W, Petit MA, Wahl S, Budkowska A. Characterization of monoclonal antibodies specific for the pre-S2 region of the hepatitis B virus envelope protein. Mol Immunol 1986;23:991-7.

29. Hunt CM, McGill JM, Allen MI, Condreay LD. Clinical relevance of hepatitis B viral mutations. Hepatology 2000;31:1037-44.

30. Locarnini S, Zoulim F. Molecular genetics of HBV infection. Anti Ther 2010;15:3-14.

31. Pollicino T, Cacciola I, Saffioti F, Raimondo G. Hepatitis B virus PreS/S gene variants: pathobiology and clinical implications. $J$ Hepatol 2014;61:408-17.

32. Hsu HY, Chang MH, Ni YH, Lin HH, Wang SM, Chen DS. Surface gene mutants of hepatitis B virus in infants who develop acute or chronic infections despite immunoprophylaxis. Hepatology 1997;26:786-91.

33. Clements CJ, Coghlan B, Creati M, Locarnini S, Tedder RS, Torresi J. Global control of hepatitis B virus: does treatment-induced antigenic change affect immunization? Bull World Health Organ 2010;88:66-73.

34. Yamamoto K, Horikita M, Tsuda F, Itoh K, Akahane Y, Yotsumoto S, Okamoto H, Miyakawa Y, Mayumi M. Naturally occurring escape mutants of hepatitis B virus with various mutations in the $\mathrm{S}$ gene in carriers seropositive for antibody to hepatitis B surface antigen. $J$ Virol 1994;68:2671-6.

35. Raimondo G, Costantino L, Caccamo G, Pollicino T, Squadrito G, Cacciola I, Brancatelli S. Non-sequencing molecular approaches to identify preS2-defective hepatitis B virus variants proved to be associated with severe liver diseases. J Hepatol 2004;40:515-9.

36. Pollicino T, Saitta C, Raimondo G. Hepatocellular carcinoma: the point of view of the hepatitis B virus. Carcinogenesis 2011;32:1122-32.

37. Kay A, Zoulim F. Hepatitis B virus genetic variability and evolution. Virus Res 2007;127:164-76. 
38. Fan YF, Lu CC, Chen WC, Yao WJ, Wang HC, Chang TT, Lei HY, Shiau AL, Su LJ. Prevalence and significance of hepatitis B virus (HBV) pre-S mutants in serum and liver at different replicative stages of chronic HBV infection. Hepatology 2001;33:277-86.

39. Liu S, Zhang H, Gu C, Yin J, He Y, Xie J, Cao G. Associations between hepatitis B virus mutations and the risk of hepatocellular carcinoma: a meta-analysis. J Natl Cancer Inst 2009;101:1066-82.

40. Carman WF, Zanetti AR, Karayiannis P, Waters J, Manzillo G, Tanzi E, Zuckerman AJ, Thomas HC. Vaccine-induced escape mutant of hepatitis B virus. Lancet 1990;336:325-9.

41. Biswas S, Candotti D, Allain JP. Specific amino acid substitutions in the S protein prevent its excretion in vitro and may contribute to occult hepatitis B virus infection. J Virol 2013;87:7882-92.

42. Pollicino T, Zanetti AR, Cacciola I, Petit MA, Smedile A, Campo S, Sagliocca L, Pasquali M, Tanzi E, Longo G, Raimondo G. Pre-S2 defective hepatitis B virus infection in patients with fulminant hepatitis. Hepatology 1997;26:495-9.

43. Bock CT, Tillmann HL, Maschek HJ, Manns MP, Trautwein C. A preS mutation isolated from a patient with chronic hepatitis B infection leads to virus retention and misassembly. Gastroenterology 1997;113:1976-82.

44. Li F, Li X, Yan T, Liu Y, Cheng Y, Xu Z, Shao Q, Liao H, Huang P, Li J, Chen GF, Xu D. The preS deletion of hepatitis B virus (HBV) is associated with liver fibrosis progression in patients with chronic HBV infection. Hepatol Int 2018;12:107-17.

45. Wang HC, Wu HC, Chen CF, Fausto N, Lei HY, Su LJ. Different types of ground glass hepatocytes in chronic hepatitis B virus infection contain specific pre-S mutants that may induce endoplasmic reticulum stress. Am J Pathol 2003;163:2441-9.

46. Fan YF, Lu CC, Chang YC, Chang TT, Lin PW, Lei HY, Su LJ. Identification of a pre-S2 mutant in hepatocytes expressing a novel marginal pattern of surface antigen in advanced diseases of chronic hepatitis B virus infection. J Gastroenterol Hepatol 2000;15:519-28.

47. Tsai HW, Lin YJ, Lin PW, Wu HC, Hsu KH, Yen CJ, Chan SH, Huang W, Su LJ. A clustered ground-glass hepatocyte pattern represents a new prognostic marker for the recurrence of hepatocellular carcinoma after surgery. Cancer 2011;117:2951-60.

48. Huang SF, Chen YT, Lee WC, Chang IC, Chiu YT, Chang Y, Tu HC, Yuh CH, Matsuura I, Shih LY, Lai MW, Wu HD, Chen MF, Yeh $\mathrm{CT}$. Identification of transforming hepatitis B virus $\mathrm{S}$ gene nonsense mutations derived from freely replicative viruses in hepatocellular carcinoma. PLoS One 2014;9:e89753.

49. Li ZQ, Linghu E, Jun W, Cheng J. Screening of hepatocyte proteins binding with C-terminally truncated surface antigen middle protein of hepatitis B virus (MHBst167) by a yeast two-hybrid system. Mol Med Rep 2014;10:1259-63.

50. Siburian MD, Suriapranata IM, Wanandi SI. Pre-S2 start codon mutation of hepatitis B virus subgenotype B3 effects on NF-kappaB expression and activation in Huh7 cell lines. Viral Immunol 2018; doi: 10.1089/vim.2017.0158.

51. Huy TT, Ushijima H, Win KM, Luengrojanakul P, Shrestha PK, Zhong ZH, Smirnov AV, Taltavull TC, Sata T, Abe K. High prevalence of hepatitis B virus pre-s mutant in countries where it is endemic and its relationship with genotype and chronicity. $J$ Clin Microbiol 2003;41:5449-55.

52. Kao JH, Liu CJ, Jow GM, Chen PJ, Chen DS, Chen BF. Fine mapping of hepatitis B virus pre-S deletion and its association with hepatocellular carcinoma. Liver Int 2012;32:1373-81.

53. Zhang D, Dong P, Zhang K, Deng L, Bach C, Chen W, Li F, Protzer U, Ding H, Zeng C. Whole genome HBV deletion profiles and the accumulation of preS deletion mutant during antiviral treatment. BMC Microbiol 2012;12:307.

54. Fang ZL, Sabin CA, Dong BQ, Wei SC, Chen QY, Fang KX, Yang JY, Huang J, Wang XY, Harrison TJ. Hepatitis B virus pre-S deletion mutations are a risk factor for hepatocellular carcinoma: a matched nested case-control study. J General Virol 2008;89:2882-90.

55. Chen CH, Hung CH, Lee CM, Hu TH, Wang JH, Wang JC, Lu SN, Changchien CS. Pre-S deletion and complex mutations of hepatitis B virus related to advanced liver disease in HBeAg-negative patients. Gastroenterology 2007;133:1466-74.

56. Huang HP, Hsu HY, Chen CL, Ni YH, Wang HY, Tsuei DJ, Chiang CL, Tsai YC, Chen HL, Chang MH. Pre-S2 deletions of hepatitis B virus and hepatocellular carcinoma in children. Pediatr Res 2010;67:90-4.

57. Abe K, Thung SN, Wu HC, Tran TT, Le Hoang P, Truong KD, Inui A, Jang JJ, Su LJ. Pre-S2 deletion mutants of hepatitis B virus could have an important role in hepatocarcinogenesis in Asian children. Cancer Sci 2009;100:2249-54.

58. Hildt E, Munz B, Saher G, Reifenberg K, Hofschneider PH. The PreS2 activator MHBs(t) of hepatitis B virus activates c-raf-1/Erk2 signaling in transgenic mice. EMBO J 2002;21:525-35.

59. Lauer U, Weiss L, Hofschneider PH, Kekule AS. The hepatitis B virus pre-S/S(t) transactivator is generated by 3' truncations within a defined region of the S gene. J Virol 1992;66:5284-9.

60. Caselmann WH. Transactivation of cellular gene expression by hepatitis B viral proteins: a possible molecular mechanism of hepatocarcinogenesis. J Hepatol 1995;22:34-7.

61. Liang X, Du J, Liu Y, Cui M, Ma C, Han L, Qu Z, Zhang Z, Sun Z, Zhang L, Chen YH, Sun W. The hepatitis B virus protein MHBs(t) sensitizes hepatoma cells to TRAIL-induced apoptosis through ERK2. Apoptosis 2007;12:1827-36.

62. Zhang X, Gao L, Liang X, Guo M, Wang R, Pan Y, Liu P, Zhang F, Guo C, Zhu F, Qu C, Ma C. HBV preS2 transactivates FOXP3 expression in malignant hepatocytes. Liver Int 2015;35:1087-94.

63. Luan F, Liu B, Zhang J, Cheng S, Zhang B, Wang Y. Correlation between HBV protein preS2 and tumor markers of hepatocellular carcinoma. Pathol Res Pract 2017;213:1037-42.

64. Fu X, Tan D, Hou Z, Hu Z, Liu G. MiR-338-3p is down-regulated by hepatitis B virus X and inhibits cell proliferation by targeting the 3'-UTR region of CyclinD1. Int J Mol Sci 2012;13:8514-39.

65. Xu H, Zhao L, Fang Q, Sun J, Zhang S, Zhan C, Liu S, Zhang Y. MiR-338-3p inhibits hepatocarcinoma cells and sensitizes these cells to sorafenib by targeting hypoxia-induced factor 1alpha. PLoS One 2014;9:e115565.

66. Liu P, Zhang H, Liang X, Ma H, Luan F, Wang B, Bai F, Gao L, Ma C. HBV preS2 promotes the expression of TAZ via miRNA-338-3p to enhance the tumorigenesis of hepatocellular carcinoma. Oncotarget 2015;6:29048-59. 
67. Awe K, Lambert C, Prange R. Mammalian BiP controls posttranslational ER translocation of the hepatitis B virus large envelope protein. FEBS Lett 2008;582:3179-84.

68. Kadowaki H, Nishitoh H, Ichijo H. Survival and apoptosis signals in ER stress: the role of protein kinases. J Chem Neuroanat 2004;28:93-100

69. Reddy RK, Mao C, Baumeister P, Austin RC, Kaufman RJ, Lee AS. Endoplasmic reticulum chaperone protein GRP78 protects cells from apoptosis induced by topoisomerase inhibitors: role of ATP binding site in suppression of caspase-7 activation. $J$ Biol Chem 2003;278:20915-24

70. Bi M, Naczki C, Koritzinsky M, Fels D, Blais J, Hu N, Harding H, Novoa I, Varia M, Raleigh J, Scheuner D, Kaufman RJ, Bell J, Ron D, Wouters BG, Koumenis C. ER stress-regulated translation increases tolerance to extreme hypoxia and promotes tumor growth. EMBO J 2005;24:3470-81.

71. Shuda M, Kondoh N, Imazeki N, Tanaka K, Okada T, Mori K, Hada A, Arai M, Wakatsuki T, Matsubara O, Yamamoto N, Yamamoto M. Activation of the ATF6, XBP1 and GRP78 genes in human hepatocellular carcinoma: a possible involvement of the ER stress pathway in hepatocarcinogenesis. J Hepatol 2003;38:605-14.

72. Hsieh YH, Su IJ, Wang HC, Chang WW, Lei HY, Lai MD, Chang WT, Huang W. Pre-S mutant surface antigens in chronic hepatitis B virus infection induce oxidative stress and DNA damage. Carcinogenesis 2004;25:2023-32.

73. Hsieh YH, Hsu JL, Su LJ, Huang W. Genomic instability caused by hepatitis B virus: into the hepatoma inferno. Front Biosci 2011;16:2586-97.

74. Teng CF, Wu HC, Shyu WC, Jeng LB, Su LJ. Pre-S2 mutant-induced mammalian target of rapamycin signal pathways as potential therapeutic targets for hepatitis B virus-associated hepatocellular carcinoma. Cell Transplant 2017;26:429-38.

75. Wang LH, Huang W, Lai MD, Su LJ. Aberrant cyclin A expression and centrosome overduplication induced by hepatitis B virus pre-S2 mutants and its implication in hepatocarcinogenesis. Carcinogenesis 2012;33:466-72.

76. Hsieh YH, Chang YY, Su IJ, Yen CJ, Liu YR, Liu RJ, Hsieh WC, Tsai HW, Wang LH, Huang W. Hepatitis B virus pre-S2 mutant large surface protein inhibits DNA double-strand break repair and leads to genome instability in hepatocarcinogenesis. $J$ Pathol 2015;236:337-47.

77. Hung JH, Su LJ, Lei HY, Wang HC, Lin WC, Chang WT, Huang W, Chang WC, Chang YS, Chen CC, Lai MD. Endoplasmic reticulum stress stimulates the expression of cyclooxygenase-2 through activation of NF-kappaB and pp38 mitogen-activated protein kinase. J Biol Chem 2004;279:46384-92.

78. Laplante M, Sabatini DM. mTOR signaling at a glance. J Cell Sci 2009;122:3589-94.

79. Teng CF, Hsieh WC, Wu HC, Lin YJ, Tsai HW, Huang W, Su LJ. Hepatitis B virus Pre-S2 mutant induces aerobic glycolysis through mammalian target of rapamycin signal cascade. PLoS One 2015;10:e122373.

80. Hudu SA, Malik YA, Niazlin MT, Harmal NS, Sekawi Z. An overview of hepatitis B virus surface antigen mutant in the Asia Pacific. Curr Issues Mol Biol 2014;16:69-78.

81. Stevens CE, Toy PT, Tong MJ, Taylor PE, Vyas GN, Nair PV, Gudavalli M, Krugman S. Perinatal hepatitis B virus transmission in the United States. Prevention by passive-active immunization. JAMA 1985;253:1740-5.

82. Pol S, Michel ML. Therapeutic vaccination in chronic hepatitis B virus carriers. Expert Rev Vaccines 2006;5:707-16.

83. Roggendorf M, Schulte I, Xu Y, Lu M. Therapeutic vaccination in chronic hepatitis B: preclinical studies in the woodchuck model. $J$ Viral Hepat 2007;14:51-7.

84. Papatheodoridis GV, Manolakopoulos S, Dusheiko G, Archimandritis AJ. Therapeutic strategies in the management of patients with chronic hepatitis B virus infection. Lancet Infect Dis 2008;8:167-78.

85. Wu CY, Chen YJ, Ho HJ, Hsu YC, Kuo KN, Wu MS, Lin JT. Association between nucleoside analogues and risk of hepatitis B virusrelated hepatocellular carcinoma recurrence following liver resection. JAMA 2012;308:1906-14.

86. Manesis EK, Papatheodoridis GV, Tiniakos DG, Hadziyannis ES, Agelopoulou OP, Syminelaki T, Papaioannou C, Nastos T, Karayiannis P. Hepatitis B surface antigen: relation to hepatitis B replication parameters in HBeAg-negative chronic hepatitis B. $J$ Hepatol 2011;55:61-8.

87. Reijnders JG, Rijckborst V, Sonneveld MJ, Scherbeijn SM, Boucher CA, Hansen BE, Janssen HL. Kinetics of hepatitis B surface antigen differ between treatment with peginterferon and entecavir. $J$ Hepatol 2011;54:449-54.

88. Jaroszewicz J, Ho H, Markova A, Deterding K, Wursthorn K, Schulz S, Bock CT, Tillmann HL, Manns MP, Wedemeyer H, Cornberg M. Hepatitis B surface antigen (HBsAg) decrease and serum interferon-inducible protein-10 levels as predictive markers for HBsAg loss during treatment with nucleoside/nucleotide analogues. Antivir Ther 2011;16:915-24.

89. Ghany MG, Doo EC. Antiviral resistance and hepatitis B therapy. Hepatology 2009;49:S174-84.

90. Perrillo R. Benefits and risks of interferon therapy for hepatitis B. Hepatology 2009;49:S103-11.

91. Malhotra JD, Miao H, Zhang K, Wolfson A, Pennathur S, Pipe SW, Kaufman RJ. Antioxidants reduce endoplasmic reticulum stress and improve protein secretion. Proc Natl Acad Sci U S A 2008;105:18525-30.

92. Tsai JJ, Kuo HC, Lee KF, Tsai TH. Glycyrrhizin represses total parenteral nutrition-associated acute liver injury in rats by suppressing endoplasmic reticulum stress. Int J Mol Sci 2013;14:12563-80.

93. Kumada H. Long-term treatment of chronic hepatitis C with glycyrrhizin [stronger neo-minophagen C (SNMC)] for preventing liver cirrhosis and hepatocellular carcinoma. Oncology 2002;62:94-100. 